\title{
Erratum to: Implementation of a methodology for determining elastic properties of lipid assemblies from molecular dynamics simulations
}

Niklaus Johner ${ }^{1 *}$, Daniel Harries ${ }^{2}$ and George Khelashvili ${ }^{3}$

Unfortunately, the original version of this article [1] contained an error. The incorrect version of Scheme 4 was used and Scheme 4 and 6 were also accidentally interchanged during processing. The correct schema and labelling is presented below.

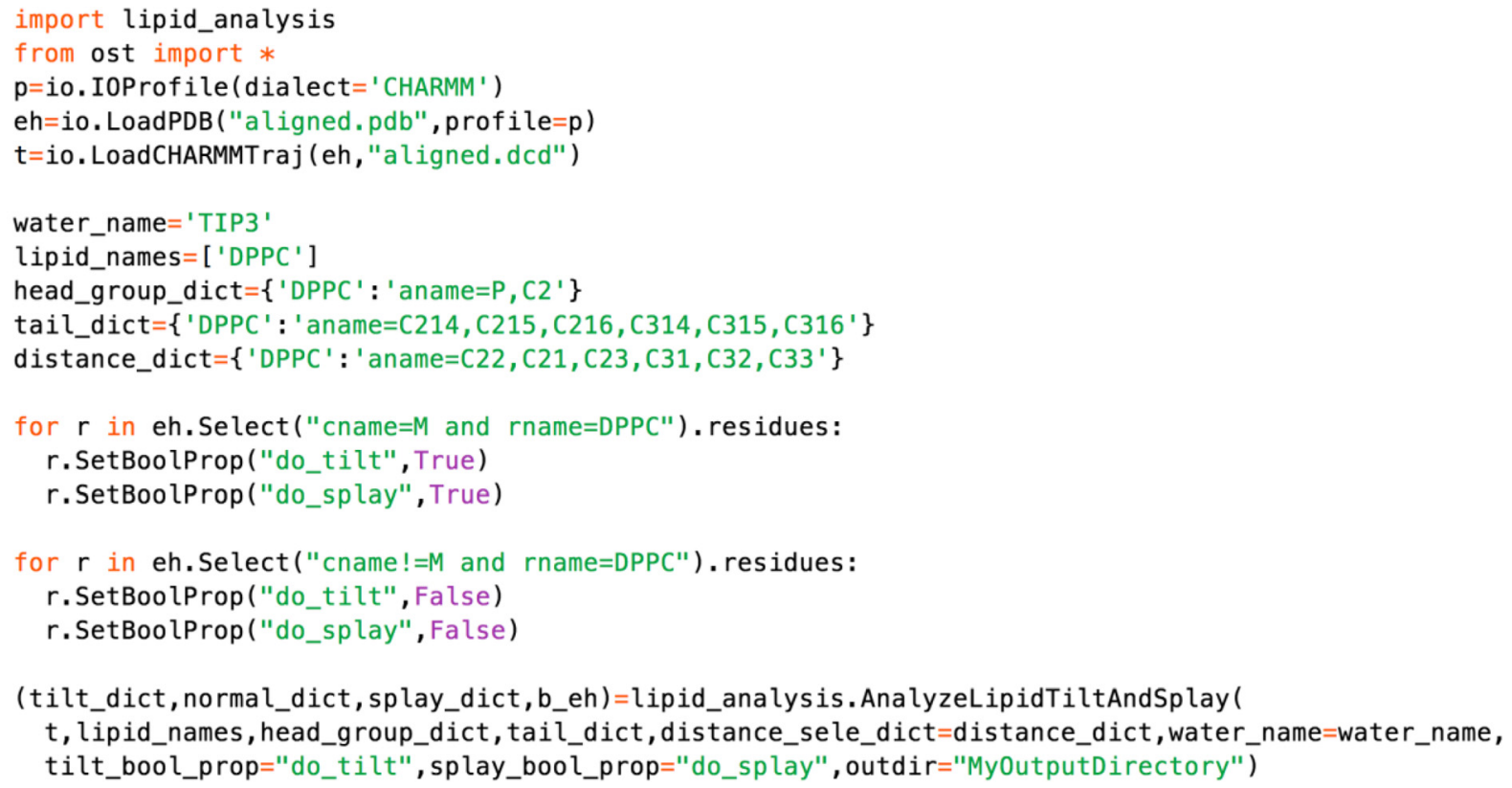

Scheme 4. Calculating lipid tilts and splays

* Correspondence: niklaus.johner@a3.epfl.ch

'Swiss Institute of Bioinformatics, Klingelbergstrasse 50/70, Basel, Switzerland

Full list of author information is available at the end of the article 


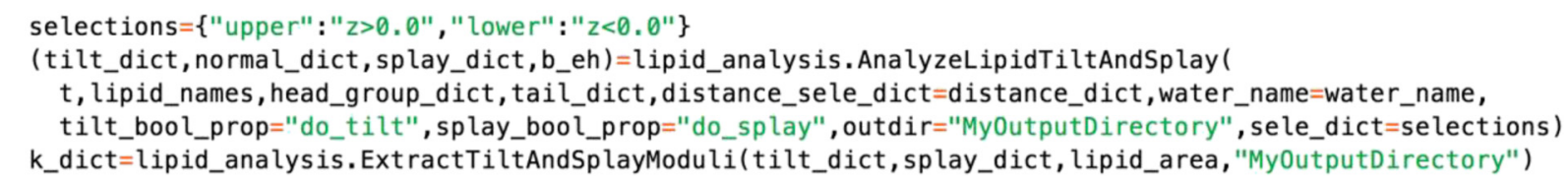

Scheme 6. Calculate tilts and splays for each leaflet of a planar bilayer separately

\section{Author details}

${ }^{1}$ Swiss Institute of Bioinformatics, Klingelbergstrasse 50/70, Basel, Switzerland.

${ }^{2}$ Institute of Chemistry and the Fritz Haber Research Center, The Hebrew

University, Jerusalem 91904, Israel. ${ }^{3}$ Department of Physiology and

Biophysics, Weill Medical College of Cornell University, New York, NY 10065,

USA.

Received: 23 May 2016 Accepted: 23 May 2016

Published online: 14 June 2016

\section{Reference}

1. Johner N, Harries D, Khelashvili G. Implementation of a methodology for determining elastic properties of lipid assemblies from molecular dynamics simulations. BMC Bioinformatics. 2016;17:161.

Submit your next manuscript to BioMed Central and we will help you at every step:

- We accept pre-submission inquiries

- Our selector tool helps you to find the most relevant journal

- We provide round the clock customer support

- Convenient online submission

- Thorough peer review

- Inclusion in PubMed and all major indexing services

- Maximum visibility for your research

Submit your manuscript at www.biomedcentral.com/submit 